\title{
ANALISIS MODEL KONSEPTUAL DEBIT AIR PADA DAS INDRAGIRI HILIR MENGGUNAKAN MODEL IHACRES
}

\author{
Jusatria \\ Program Studi Teknik Sipil, Fakultas Teknik, Universitas Islam Indragiri, Tembilahan \\ Email: jusatria2901@gmail.com (korespondensi)
}

\begin{abstract}
The modelling of Indragiri Hilir drainage basin is very necessary, considered by Indragiri Hilir area which sometimes overflows into residential areas and disturbs residents' activities. Conceptual analysis of water discharge through the Ihacres software could help to analyze the flow of Indragiri Hilir drainage basin. Rainfall-runoff modeling is used to predict runoff values, one of which is the IHACRES model. The IHACRES model produces nonlinear loss module parameters and linear hydrograph module units. AWLR that will be used is Kuantan Rengat station, Rain Data that will be used are from Tembilahan station and climatology from Air Molek station. Determination of the success of the model used equation $R 2$ and $R$ to calculate the deviation that occurs. The calibration, verification and simulation phase starts in 2010-2015. The result of conceptual analysis of water discharge of Indragiri Hilir drainage basin, In the calibration stage of the IHACRES Model, the best scheme is scheme 2 with R2 value 0.861 and $R$ value 0.864 . While the verification phase is carried out with the following year the best scheme is scheme 3 with the highest $R 2$ value with $R 2-2,550$ and $R$-value 1,603 and the simulation scheme is the best scheme 5 with $R 2-1,904$ and $R-1,341$.
\end{abstract}

Keywords: IHACRES, Calibration, Verification, Simulation

\begin{abstract}
Abstrak
Permodelan debit pada DAS indragiri hilir sangat diperlukan mengingat wilayah indragiri hilir yang terkadang air yang meluap hingga ke pemukiman penduduk dan mengganggu aktivitas warga. Analisis konseptual debit air dengan bantuan software ihacres dapat membantu menganalisis debit DAS indragiri hilir. Pemodelan rainfall-runoff digunakan untuk memprediksi nilai terhadap runoff salah satunya yaitu menggunakan model IHACRES. Model IHACRES menghasilkan parameter nonlinier loss module dan linier unit hydrograph module. AWLR yang akan digunakan yaitu stasiun Bt. Kuantan Rengat, Data Hujan yang akan digunakan yaitu dari stasiun Tembilahan dan klimatologi yang digunakan dari stasiun Air Molek. Penentuan keberhasilan pada model digunakan persamaan $R 2$ dan $R$ untuk menghitung simpangan yang terjadi. Tahap kalibrasi, verifikasi dan simulasi dimulai tahun 2010-2015. Hasil analisis konseptual debit air pada DAS Indragiri Hilir, Pada tahap kalibrasi Model IHACRES nilai Skema terbaik yaitu skema 2 dengan R2 0,861 dan R 0,864. Sedangkan tahap verifikasi nilai skema terbaik yaitu skema 3 dengan nilai $R 2-2,550$ dan $R-1,603$ dan pada tahap simulasi nilai skema terbaik yaitu skema 5 dengan $R 2-1,904$ dan $R-1,341$.
\end{abstract}

Kata kunci: IHACRES, Kalibrasi, Verifikasi, Simulasi

\section{Pendahuluan}

Melihat kondisi Daerah aliran sungai (DAS) Indragiri hilir yang kadang meluap secara tiba-tiba ke permukaan perlunya dilakukan peninjauan dalam evaluasi debit untuk itu perlu ditinjau secara konseptualisasi. Pergerakan air yang dapat dideteksi dan didekati dengan beberapa persamaan matematika. Persamaan tersebut mencerminkan proses pengalihragaman dari hujan menjadi aliran yang dapat ditiru dan disederhanakan serta diwujudkan dalam bentuk model, yang disebut dengan model hujan aliran. Pendekatan yang digunakan untuk membangun suatu pemodelan curah hujan menjadi debit aliran sungai dimana dapat menentukan parameter yang dinginkan oleh peneliti.

Pada penggunaan pemodelan ini banyak parameter yang berpengaruh seperti input data, nilai dari parameter yang ditetapkan, struktur pemodelan dan lain-lain. Salah satu cara yang umum dari suatu pemodelan adalah mengembangkan model dari suatu pemodelan yang kemudian di modifikasi.

Pemodelan rainfall-runoff yang digunakan biasanya dikarenakan sering terbatas 
ketersediaan data debit dari aliran sungai yang ditinjau. Dalam pemodelan rainfallrunoff ini biasanya melibatkan analisa statistik untuk memprediksi data ke depan. Salah satunya adalah Model IHACRES adalah model hujan aliran yang cukup dikenal dan banyak diaplikasikan di beberapa negara di dunia oleh para praktisi dan peneliti. Model IHACRES (Identification of Unit Hydrograph and Component Flow from Rainfall, Evaporation and Stream Flow Data) dikembangkan di Inggris, dengan mendeskripsikan hujan aliran menjadi dua sub proses yakni sub proses vertikal yang digambarkan oleh Non Linear Loss Module dan sub proses lateral yang diimplementasikan melalui Linear Unit Hydrograph Module (Indarto, 2010). Pada daerah Riau penelitian yang telah berhasil dilakukan oleh Ryan Adi Wibowo (2013) dalam menyelidiki respon hidrologi di DAS Indragiri. Hasil penelitian tersebut menunjukan kinerja yang baik. Untuk memastikan keandalan menggunakan model IHACRES dalam memodelkan hujan aliran pada DAS Indragiri Hilir seberapa besarnya debit aliran permukaan sungai.

\section{TINJAUAN PUSTAKA}

Model yang muncul kebanyakan adalah hasil pengembangan dari model terdahulu. Banyak model rainfall-runoff yang sudah dikembangkan diantaranya: tank model (sugawara, 1995), IHACRES (Ye, 1997), HBV (Lindstrom, 1997), SMAR (Tan dan O'Connor, 1996), TOPMODEL (Beven,1986), Xianjiang (Jayawardena dan Zhou, 2000) dan masih banyak lagi

\subsection{Pemodelan}

Model adalah suatu perkiraan atau penyederhanaan siklus hidrologi dari realitas yang sebenarnya.

\subsection{Model IHACRES}

Model IHACRES tergolong model hujan aliran yang input utama adalah data hujan, data debit dan data suhu untuk menghitung nilai evapotranspirasi. Selanjutnya model IHACRES akan memprediksi atau menghitung debit yang keluar dari DAS.

Konsep Model IHACRES disederhanakan sebagai berikut:

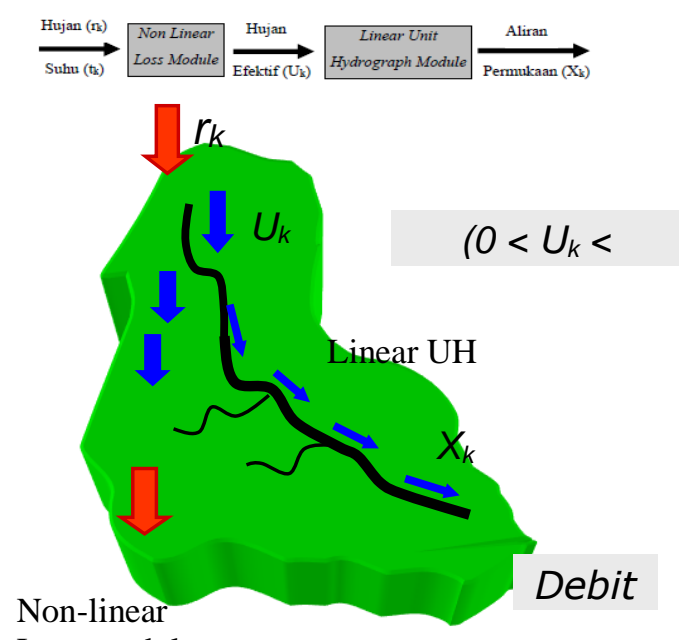

Loss module

Gambar 1. Konsep model IHECRAS

Gambar 1 dilihat proses hujan aliran dibedakan menjadi dua. Sub-proses vertical yang digambarkan oleh non-linier-lossmodule dan sub-proses lateral yang diimplementasikan melalui linier-unithydrograph-module. Non linier loss module berfungsi untuk mengkonversi hujan menjadi hujan efektif. Modul ini bekerja seperti persamaan infiltrasi. Masukan utama modul ini adalah hujan (rk) dan data suhu (tk). Data suhu digunakan untuk menghitung evaporasi didalam DAS. Selanjutnya, hujan efektif (uk) yang dihasilkan dari non linear loss module, ditransfer secara lateral melalui linier unit hydrograph module menjadi aliran permukaan berupa debit terhitung (debit simulasi) di outlet DAS (Indarto,2010).

Menurut Sriwongsitanon dan Taesombat (2011)Untuk menentukan range parameter pada model IHACRES dapat kita lihat sebagai berikut :

Tabel 1. Range Parameter Model IHACRES

\begin{tabular}{|l|c|}
\hline \multicolumn{1}{|c|}{ Parameter Model } & $\begin{array}{c}\text { Range Parameter } \\
\text { Model }\end{array}$ \\
\hline $\begin{array}{l}\text { Keseimbangan massa } \\
(\mathrm{c})\end{array}$ & $0,003-0,011$ \\
\hline $\begin{array}{l}\text { Modulasi temperatur } \\
(\mathrm{f})\end{array}$ & $1-9$ \\
\hline $\begin{array}{l}\text { Laju pengeringan } \\
\text { pada saat suhu } \\
\text { referensi }\left(\tau_{\mathrm{w}}\right)\end{array}$ & $0,5-15$ \\
\hline $\begin{array}{l}\text { Konstanta waktu } \\
\text { respon cepat }\left(\tau_{\mathrm{q}}\right)\end{array}$ & $2-200$ \\
\hline $\begin{array}{l}\text { konstanta waktu } \\
\text { respon lambat }\left(\tau_{\mathrm{s}}\right)\end{array}$ & $0,02-0,95$ \\
\hline $\begin{array}{l}\text { Volume perbandingan } \\
\text { untuk aliran lambat } \\
\left(\mathrm{v}_{\mathrm{s}}\right)\end{array}$ & \\
\hline
\end{tabular}


Dari Tabel 1. Model IHACRES memiliki enam parameter model, tiga diantaranya berkaitan dengan non linear loss module yaitu $\tau_{w}, f$ dan $c$ serta tiga parameter berikutnya berkaitan dengan linear unit hydrograph module yaitu $\tau_{\mathrm{q}} \tau_{\mathrm{s}}$ dan $\mathrm{v}_{\mathrm{s}}$. Keenam parameter model tersebut dianggap sebagai upaya dalam karakterisasi yang unik dan efisien dari proses hidrologi pada sebuah DAS.

\subsection{Kalibrasi Model}

Tahap kalibrasi
menggunakan dilakukan
pemilihan periode kalibrasi dan periode
warm up. Kalibrasi pada suatu mode
adalah pemilihan terhadap suatu
adalah pemilihan terhadap suatu kombinasi parameter. Poses optimalisasi nilai parameter untuk meningkatkan koherensi atara respon hidrologi DAS yang teramati dan tersimulasi (Bloschl and Grayson, 2000), pemilihan periode kalibrasi diawali dan diakhiri pada keadaan debit relatif kecil sehingga perubahan penyimpanan air di DAS selama periode kalibrasi dapat diasumsikan mendekati nol. Pemilihan periode warm up bertujuan untuk mengisi kondisi awal DAS

kalibrasi dilakukan yang dilakukan, perlu adanya pengecekan kriteria statistik yaitu $\mathrm{R}^{2}$ dan bias sebagai indikator bagus atau tidaknya hasil kalibrasi yang dihasilkan.

Menurut Motovilov, dkk (1999) Untuk menentukan keandalan model adalah $\mathrm{R}^{2}$ dan R. Kedua indikator statistik tersebut cukup dalam mengevaluasi kinerja model dalam hal membandingkan antara hasil simulasi model dengan data yang observasi. Nilai optimal untuk $\mathrm{R}^{2}$ mendekati satu dan bias mendekati nol.

Penyimpangan yang terjadi pada metode $\mathrm{R}^{2}$ (Nash-SutcliffeCoefficient) dapat dirumuskan:

$$
R^{2}=1-\frac{\sum_{i=1}^{n}\left(Q_{S i}-Q_{M i}\right)^{2}}{\sum_{i=1}^{n}\left(Q_{M i}-Q_{m}\right)^{2}} \times 100 \%
$$

Dengan :

$$
\begin{array}{llll}
\mathrm{R}^{2}=\text { Koefisien } \mathrm{R}^{2} & & \\
\mathrm{Q}_{\mathrm{Si}}=\text { Debit Nilai } \quad \text { Simulasi } & \text { Model } \\
\left(\mathrm{m}^{3} /\right. \text { detik) } & \\
\mathrm{Q}_{\mathrm{Mi}}=\text { Debit terukur }\left(\mathrm{m}^{3} / \text { detik }\right) & \\
\mathrm{Q}_{\mathrm{m}} \quad \text { Debit } \quad \text { Rata-rata } & \text { nilai } \\
\text { terukur }\left(\mathrm{m}^{3} /\right. \text { detik) } & & \\
\mathrm{n} \quad=\text { Jumlah data } &
\end{array}
$$

$\mathrm{R}^{2}$ memiliki beberapa kriteria seperti yang diperlihatkan pada tabel 2 .

Tabel. 2 Kriteria Nilai terhadap Model IHACRES

\begin{tabular}{|c|c|}
\hline Nilai R & Interpretasi \\
\hline $\mathrm{R}^{2}>0,75$ & Baik \\
\hline $\begin{array}{c}0,36<\mathrm{R}^{2}< \\
0,75\end{array}$ & Memuaskan \\
\hline $\mathrm{R}^{2}<0,36$ & $\begin{array}{c}\text { Tidak } \\
\text { memuaskan }\end{array}$ \\
\hline
\end{tabular}

Tabel. 3 Kriteria Nilai terhadap koefisien korelasi (R)

\begin{tabular}{|c|c|}
\hline $\begin{array}{c}\text { Nilai Koefisien } \\
\text { Korelasi }(R)\end{array}$ & Interpretasi \\
\hline 0 & Tidak ada Korelasi \\
\hline $0-0,25$ & Sangat Lemah \\
\hline $0,25-0,5$ & Sedang \\
\hline $0,5-0,75$ & Kuat \\
\hline $0,75-0,99$ & Sangat Kuat \\
\hline 1 & Korelasi Sempurna \\
\hline
\end{tabular}

Bias adalah tingkat kesalahan dalam perhitungan volume aliran atau selisih antara debit terukur dan terhitung per tahun. Perhitungan bias pada IHACRES dirumuskan:

$$
\begin{aligned}
\text { Bias } & =\frac{\sum\left(Q_{o}-Q_{m}\right)}{n} \\
Q_{o} & =\text { debit terukur }\left(\mathrm{m}^{3} / \text { detik }\right) \\
Q_{m} & =\text { debit simulasi }\left(\mathrm{m}^{3} / \text { detik }\right) \\
\mathrm{n} & =\text { jumlah data }
\end{aligned}
$$

\subsection{Verifikasi Model}

Verifikasi model merupakan suatu proses setelah tahap kalibrasi selesai dilakukan yang berfungsi untuk menguji kinerja model pada data diluar periode kalibrasi. Kinerja model biasanya lebih baik selama periode kalibrasi dibanding verifikasi, fenomena seperti ini disebut dengan divergensi model. Ketika tingkat divergensi tidak dapat diterima, maka pemodel harus memeriksa struktur model dan prosedur kalibrasi yang sesuai ataupun asumsi yang pantas merevisinya (Wibowo, 2013).

\subsection{Simulasi Model}


Tahap simulasi model ini adalah proses terakhir setelah proses kalibrasi dan verifikasi dilakukan yang menggunakan seluruh data.

\section{METODOLOGI PENELITIAN}

Lokasi Penelitian dilakukan pada aliran Indragiri Hilir . luas Das yaitu seluas 4215 $\mathrm{km}^{2}$. studi dilakukan dengan menggunakan data klimatologi, data hujan dan data debit.

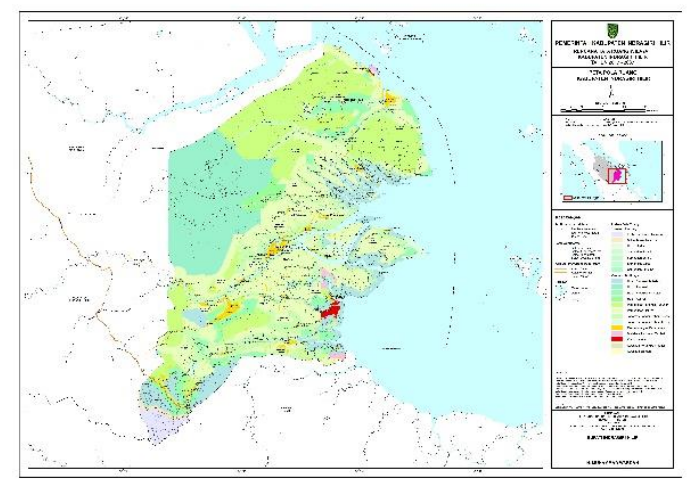

Gambar 2. Peta lokasi Penelitian

\subsection{Pengumpulan Data}

Data Skunder yang digunakan dalam penelitian ini adalah data dari Tahun 2010 hingga Tahun 2015. Berikut adalah datadata yang digunakan:

\section{Data curah hujan}

Data curah hujan berasal kecamatan Tembilahan mulai dari Tahun 2010 hingga Tahun 2015. Letak geografi stasiun koordinat : $0^{\circ} 19^{\prime} 02^{\prime \prime} \mathrm{LU} / 103^{\circ}$ 10' 00"BT dengan ketinggian dari permukaan laut $2.5 \mathrm{~m}$. Data curah hujan diperoleh dari Badan Wilayah Sungai III Pekanbaru.

2. Data Klimatologi

Data klimatologi diperoleh dari Stasiun Air Molek. Letak Geografi stasiun koordinat $0^{\circ} 22^{\prime} 00^{\prime \prime}$ LU / 102 ${ }^{\circ} 17^{\prime}$ 00"BT dengan ketinggian dari permukaan laut $16 \mathrm{~m}$. diperoleh dari Badan Wilayah Sungai III Pekanbaru .

3. Data Debit DAS Indragiri Hilir Data Debit Sungai/AWLR dari stasiun Bt. kuantan renga yaitu pada Tahun 2010 hungga Tahun 2015. Nomor Stasiun $01-66-0-15$. Data Debit diperoleh dari Badan Wilayah Sungai III Pekanbaru.

\subsection{Analisis Penelitian}

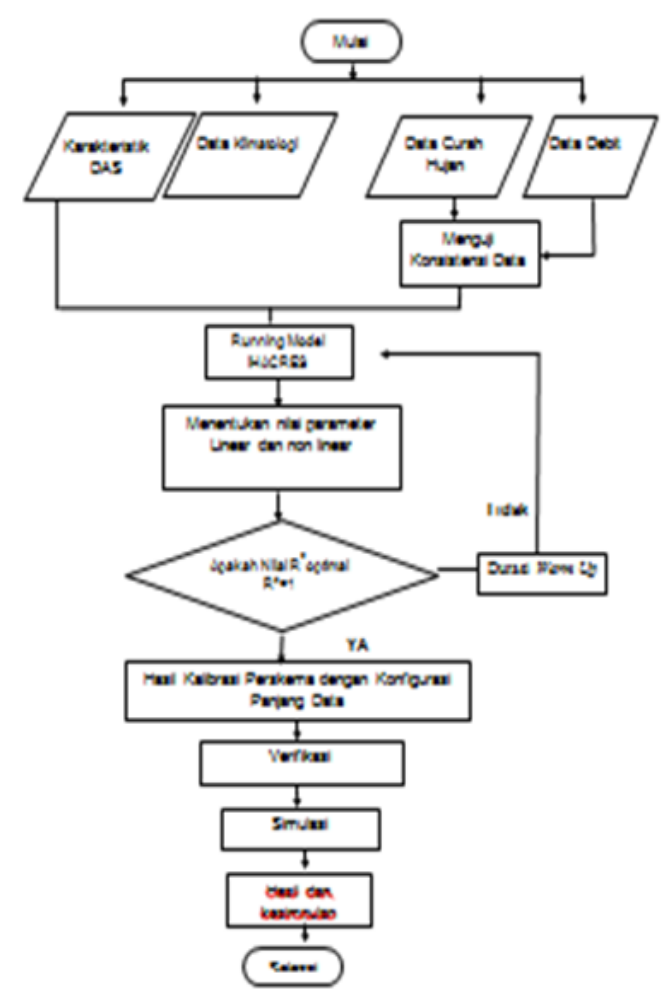

Gambar 3. Flow chart penelitian

\section{HASIL DAN PEMBAHASAN}

Tahap awal yaitu pengumpulan data skunder kemudian melakukan Uji konsistensi data digunakan untuk menguji data lapangan yang diolah konsisten atau tidak. ketidakpanggahan data suatu stasiun dengan data dari stasiun itu sendiri dengan mendeteksi pergeseran nilai rata - ratanya.

\subsection{Konfigurasi Panjang Data}

Data penelitiandilakukan selama 6 tahun (2010-2015), oleh sebab itu percobaan kalibrasi selalu dimulai dari tahun 2010, dan verifikasi menyesuaikan tahun setelah kalibrasi.dan simulasi dimulai dari tahun 2010. Untuk mempermudah membedakan percobaan, maka percobaan dilakukan dengan beberapa skema. Skema tersebut dapat dilihat pada Tabel. 4 sebagai berikut. 


\subsection{Analisis Menggunakan Kalibrasi \\ Pemodelan IHACRES}

Debit Tahap

Tahap kalibrasi dilakukan dengan program IHACRES v.2.1. Hasil nilai $\mathrm{R}^{2}$ dan bias pada tahap kalibrasi dengan variasi warm up untuk masing - masing skema. Diatas analisis pada setiap skema memberikan pemahaman bahwa variasi warm up yang memberikan nilai $\mathrm{R}^{2}$ optimal untuk masing - masing skema tidaklah sama. Sehingga dari warm up dengan $\mathrm{R}^{2}$ optimal tersebut memberikan parameter

\begin{tabular}{|c|c|c|c|}
\hline Skema & $\begin{array}{l}\text { Kalibrasi } \\
\text { (Tahun) }\end{array}$ & $\begin{array}{l}\text { Verifikasi } \\
\text { (Tahun) }\end{array}$ & $\begin{array}{l}\text { Simulasi } \\
\text { (Tahun) }\end{array}$ \\
\hline 1 & 2010 & $\begin{array}{l}2011- \\
2015\end{array}$ & $\begin{array}{l}2010- \\
2015\end{array}$ \\
\hline 2 & $\begin{array}{l}2010- \\
2011\end{array}$ & $\begin{array}{l}2012- \\
2015\end{array}$ & $\begin{array}{l}2010- \\
2015\end{array}$ \\
\hline 3 & $\begin{array}{l}2010- \\
2012 \\
\end{array}$ & $\begin{array}{l}2013- \\
2015 \\
\end{array}$ & $\begin{array}{l}2010- \\
2015 \\
\end{array}$ \\
\hline 4 & $\begin{array}{l}2010- \\
2013\end{array}$ & $\begin{array}{l}2014- \\
2015\end{array}$ & $\begin{array}{l}2010- \\
2015\end{array}$ \\
\hline 5 & $\begin{array}{l}2010- \\
2014\end{array}$ & 2015 & $\begin{array}{l}2010- \\
2015 \\
\end{array}$ \\
\hline
\end{tabular}

Tabel 4.Analisais skema terhadap Kalibrasi, Verifikasi dan Simulasi

\section{Model IHACRES}

hasil kalibrasi dan variabel seperti yang.

ditampilkan pada Tabel 5 dan Tabel 6 sebagai berikut.

Tabel 5. Nilai Parameter Hasil Kalibrasi Skema 1 hingga Skema 5

\begin{tabular}{|c|c|c|c|c|c|}
\hline Param eter Hasil Kalibrasi & Skema 1 & Skema 2 & Skema 3 & Skema 4 & Skema 5 \\
\hline \multicolumn{6}{|l|}{\begin{tabular}{|l} 
Non linear Module \\
\end{tabular}} \\
\hline Keseimbangan Massa (c) & 0,006296 & 0,017322 & 0,007189 & 0,008486 & 0,024879 \\
\hline \begin{tabular}{l|}
$\begin{array}{l}\text { Laju Pengertian pada saat suhu } \\
\text { referensi }\left(T_{v}\right)\end{array}$
\end{tabular} & 9,000 & 9,000 & 9,000 & 9,000 & 1,000 \\
\hline Modulasi Temperatur $(f)$ & 1,000 & 1,500 & 9,000 & 9,000 & 1,000 \\
\hline \multicolumn{6}{|l|}{ Linear Module } \\
\hline $\begin{array}{l}\text { Konstanta waktu respon Lambat } \\
\left(T^{(s)}\right.\end{array}$ & 51,63 & 105,295 & 105,928 & 321,989 & 846,448 \\
\hline $\begin{array}{l}\text { Volum e perbandingan untuk } \\
\text { aliran }\end{array}$ & 1,003 & 1,008 & 0,992 & 0,996 & 1,000 \\
\hline
\end{tabular}

Tabel 6. Variabel Skema 1 hingga Skema 5

\begin{tabular}{|c|c|c|c|c|c|}
\hline \begin{tabular}{|l|} 
Variabel \\
\end{tabular} & Skema 1 & Skema 2 & Skema 3 & Skema 4 & Skema 5 \\
\hline Temperatur referensi & 30,0000 & 30,0000 & 30,0000 & 30,0000 & 30,0000 \\
\hline $\begin{array}{l}\text { Indeks ambang batas kelembaban } \\
\text { tanah untuk menghasilkan aliran (1) }\end{array}$ & 0,000 & 0,000 & 0,000 & 0,000 & 0,000 \\
\hline Respon jangka w & 1,000 & 1,000 & 1,000 & 1,000 & 1,000 \\
\hline $\begin{array}{l}\text { Anga resesi untuk aliran } \\
\left(a^{(s)}\right)\end{array}$ & $-0,981$ & $-0,991$ & $-0,991$ & $-0,997$ & $-0,999$ \\
\hline $\begin{array}{l}\text { Respon } \\
\left(\beta^{(s)}\right)\end{array}$ & 0,003 & $-0,008$ & 0,008 & 0,004 & 0,002 \\
\hline $\begin{array}{l}\text { Volume Perbandingan untuk alira } \\
\text { cepat }(V(a) \text { ) }\end{array}$ & $-0,003$ & $-0,008$ & 0,008 & 0,004 & 0,001 \\
\hline
\end{tabular}

\subsection{Analisis Hasil Kalibrasi, Verifikasi dan Simulasi Skema 1 hingga Skema 5}

Pada tahap kalibrasi tahap verifikasi dan tahap simulasi dengan membandingkan masing - masing skema sehingga diperoleh skema yang memberikan estimasi terbaik dalam memodelkan hujan aliran pada stasiun duga air danau bingkuang. Adapun hasil uji statistik skema 1 hingga skema 5 .

Tabel 7. Skema Hasil Percobaan Kalibrasi, Verifikasi IHACRES

\begin{tabular}{|c|c|c|c|c|c|c|}
\hline \multirow{2}{*}{ Skem a } & \multicolumn{3}{|c|}{ Kalibrasi } & \multicolumn{3}{|c|}{ Verifikasi } \\
\cline { 2 - 7 } & $\mathrm{R}^{2}$ & $\mathrm{R}$ & Bias & $\mathrm{R}^{2}$ & $\mathrm{R}$ & Bias \\
\hline Skema 1 & 0,526 & 0,543 & 4,173 & $-8,165$ & $-3,652$ & 1179,740 \\
\hline Skema 2 & $\mathbf{0 , 8 6 1}$ & $\mathbf{0 , 8 6 4}$ & $-\mathbf{0 , 7 0 1}$ & $-4,759$ & $-5,960$ & $-636,068$ \\
\hline Skema 3 & 0,589 & 0,642 & 9,807 & $-\mathbf{2 , 5 5 0}$ & $-\mathbf{1 , 6 0 3}$ & $\mathbf{1 0 0 9 , 2 4 8}$ \\
\hline Skema 4 & 0,188 & 0,174 & $-1,339$ & $-16,893$ & $-1,603$ & 1009,248 \\
\hline Skema 5 & 0,036 & 0,032 & $-0,701$ & $-12,657$ & $-1,603$ & 1009,248 \\
\hline
\end{tabular}

Tabel 8. Skema Hasil Percobaan Simulasi IHACRES

\begin{tabular}{|l|r|r|r|}
\hline \multirow{2}{*}{ Skema } & \multicolumn{3}{|c|}{ Simulasi } \\
\cline { 2 - 4 } & $R^{2}$ & $R$ & Bias \\
\hline Skema 1 & $-3,1634$ & $-1,591$ & 129,2228 \\
\hline Skema 2 & $-5,1235$ & $-7,718$ & $-2076,6275$ \\
\hline Skema 3 & $-3,0449$ & $-4,177$ & $-1023,976$ \\
\hline Skema 4 & $-2,3123$ & $-1,713$ & 1421,0644 \\
\hline Skema 5 & $-\mathbf{1 , 9 0 4}$ & $\mathbf{- 1 , 3 4 1}$ & $\mathbf{5 2 2 , 0 5 4 6}$ \\
\hline
\end{tabular}

Berdasarkan Tabel 6 dan Tabel 7 yang memberikan estimasi terbaik dalam memodelkan hujan aliran di stasiun kuantan pada tahap kalibrasi nilai $\mathrm{R}^{2}$ tertinggi adalah skema 2 dengan nilai $R^{2} 0,861$ dan nilai $R$ tertinggi 0,864 dan pada tahap verifikasi nilai tertinggi dengan nilai $R^{2}-2.550$ dan nilai $R-1,603$ terdapat pada skema 3 sedangkan estimasi nilai terbaik pada tahap simulasi terdapat pada skema 5 dengan nilai $\mathrm{R}^{2}-1.904$ dan nilai $\mathrm{R}-1,341$. Hasil kalibrasi menunjukkan kinerja model Baik dengan kategori nilai $\left(R^{2}>0,75\right)$ pada tahap kalibrasi.

Namun yang ditunjukan berbeda diperlihatkan ketika parameter dan variabel model verifikasi dan simulasi. Hasilnya menunjukkan bahwa kinerja model tidak memenuhi $\left(R^{2}<0,36\right)$.

\subsection{Grafik Hasil dari Verifikasi dan simulasi}

Pada Grafik Verifikasi dan simulasi model IHACRES pada hidrograf yang terlihat pada gambar 3 dan gambar 4 terdapat hasil grafik dengan estimasi terbaik yang mana garis hitam yang merupakan garis untuk menandakan debit terukur yang diambil dari data debit pada Stasiun BT.kuantan Rengat, sementara itu garis yang berwarna merah merupakan debit simulasi yang berasal dari pemodelan Ihacres dan garis biru merupakan data hujan yang berasal dari Stasiun Air Molek. Berikut hasil grafik verifikasi dan simulasi. 


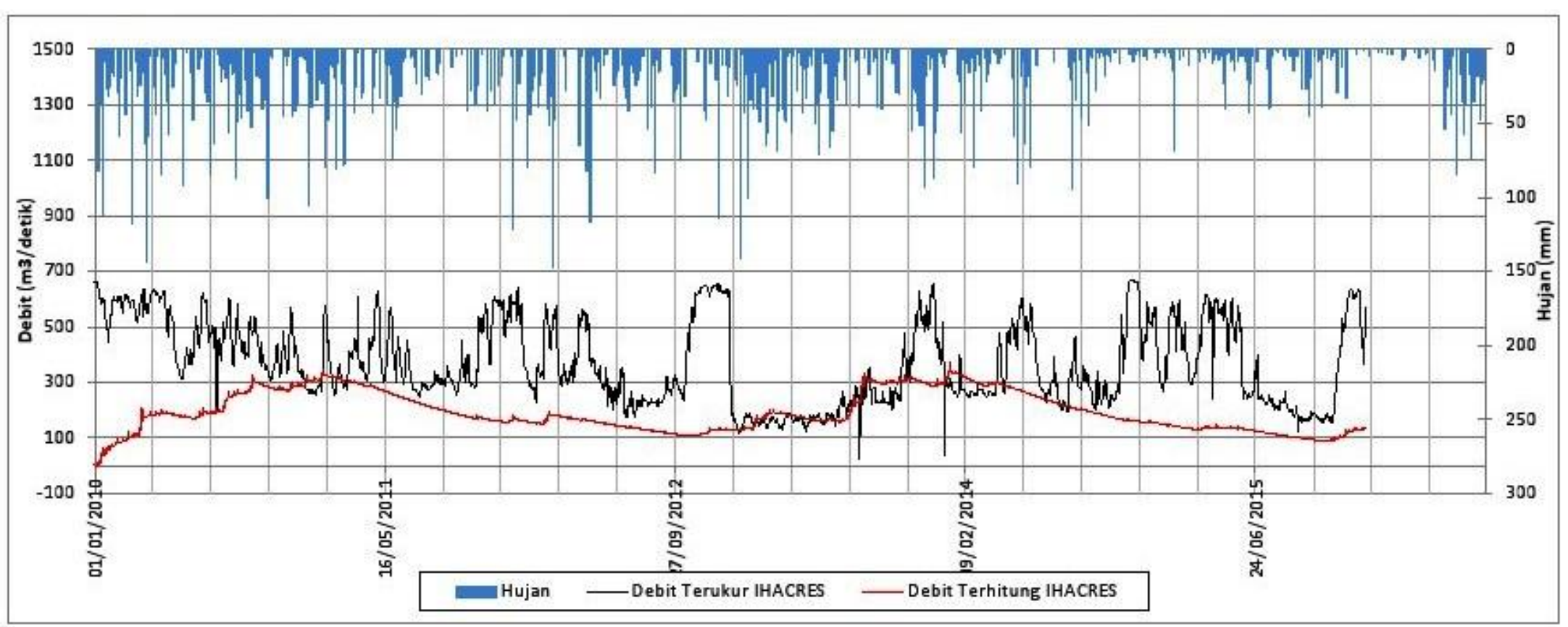

Gambar 3. Grafik Hasil Verifikasi terbaik Model IHACRES Skema 3 


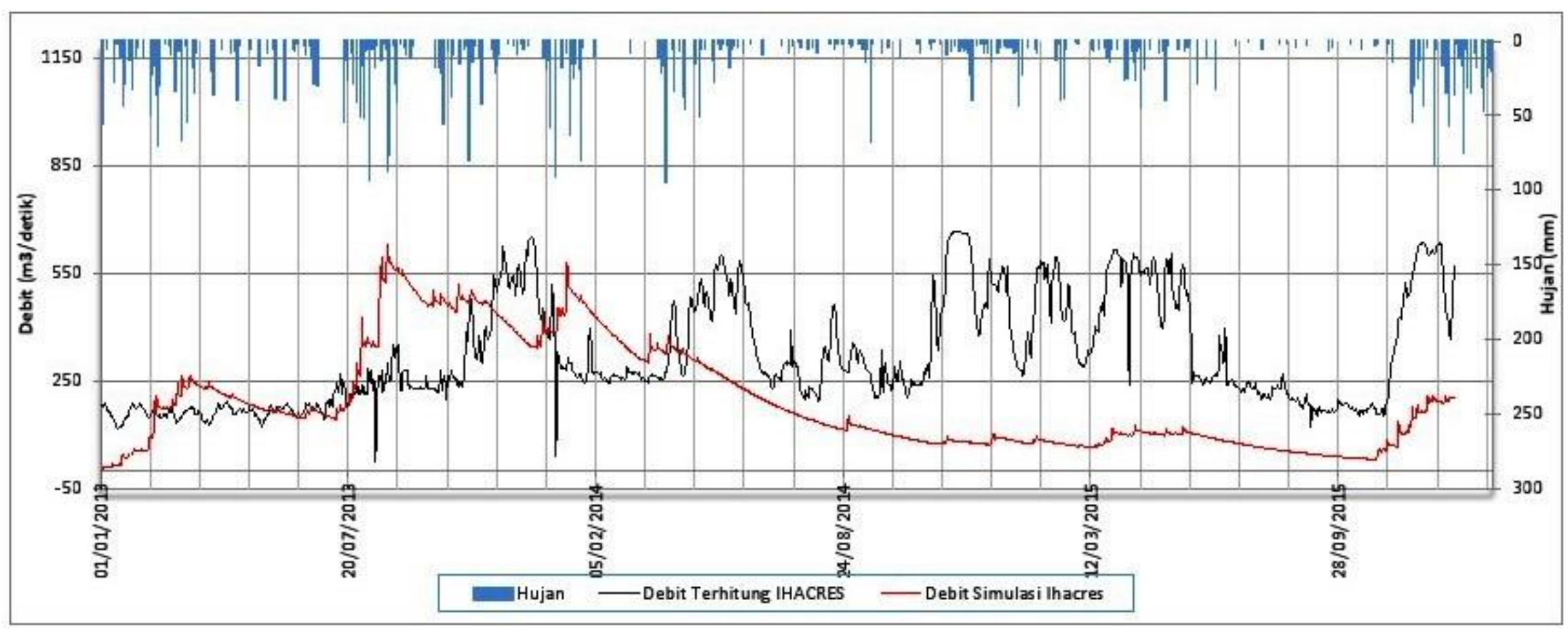

Gambar 4. Grafik Hasil Simulasi terbaik Model IHACRES Skema 4 


\section{KESIMPULAN DAN SARAN}

Hasil dari Analisis model konseptual debit air pada DAS Indragiri Hilir menggunakan model IHACRES menyatakan pada tahap kalibrasi nilai tertinggi berdasarkan nilai $\mathrm{R}^{2}$ dan $R$ yang ditampilkan dari pemodelan terletak pada skema 2dengan nilai $R^{2}$ 0,861 dan nilai $R \quad 0,864$. Selanjutnya tahap verifikasi model IHACRES nilai $R^{2}$ tertinggi terletak pada skema 3 dengan nilai $R^{2}$ 2,550 dan nilai $R-1,603$.

Tahap terakhir yaitu tahap simulasi model IHACRES nilai tertinggi $\mathrm{R}^{2}$ dan $\mathrm{R}$ terletak pada skema 5 dengan nilai $\mathrm{R}^{2}$ 1,904 dan nilai $\mathrm{R}-1,341$.

Saran lebih teliti dalam proses kalibrasi terutama pada saat running penentuan nilai $\mathrm{R}^{2}$ optimal terhadap masing-masing skema dan bisa dilanjutkan peninjauan sampai ketersediaan air bersih pada DAS Indragiri Hilir.

\section{UCAPAN TERIMA KASIH}

Terimakasih kepada pada BWSS III atas pemberian data-data untuk melengkapi penelitian ini

\section{DAFTAR PUSTAKA}

[1] Indarto, "Hidrologi Dasar Teori dan Contoh Aplikasi Model Hidrologi," Bumi askara,Jakarta, 2011.

[2] Jusatria, Analisis ketersediaan air pada DAS kampar menggunakan model IHACRES, Universitas Riau, Pekanbaru, 2020

[3] Motovilov, Y.G., Gottschalk, L., Engeland, K. \& Rodhe, Validation of a Distributed Hydrological Model Against Spatial Observations, Elsevier Agricultural and Forest Meteorology. 98 : 257-277, 1999.

[4] Sriwongsitanon, N. \& Taesombat, "Estimation of the IHACRES Model Parameters for Flood Estimation of Ungauged in the Upper Ping River Basin," Kasetsart J (Nat. Sci.) 45,2011.

[5] Sri Harto, Analisa Hidrologi, PT Gramedia Pustaka Utama, jakarta, 1993

[6] Wibowo Rian A, Analisa Hujan Aliran Menggunakan Model IHACRES. Skripsi S1.Program Studi Teknik Sipil, Universitas Riau, Pekanbaru, 2013 